\title{
Densitometer Device
}

National Cancer Institute

\section{Source}

National Cancer Institute. Densitometer Device. NCI Thesaurus. Code C50055.

A device designed to measure density. 